\title{
Synthesis of New Indolecarboxylic Acids Related to the Plant Hormone Indoleacetic Acid IAA
}

\author{
Flávia A. F. da Rosa ${ }^{a, b}$, Ricardo A. Rebelo ${ }^{*, a}$ and Maria G. Nascimento ${ }^{b}$ \\ ${ }^{a}$ Departamento de Química, Universidade Regional de Blumenau, 89010-971, Blumenau - SC, Brazil \\ ${ }^{b}$ Departamento de Química, Universidade Federal de Santa Catarina, 88040-900, Florianópolis - SC, Brazil
}

\begin{abstract}
A síntese dos ácidos 5,6-metilenodioxi-indol-3-il-metanóico 8 e 5,6-metilenodioxi-indol-3-ilacético 13 é descrita. Piperonal foi empregado como material de partida, sendo a construção do heterociclo altamente regioespecífica e está fundamentada na reação de Hemetsberger do correspondente $\beta$-azidoestireno. O composto 8 foi obtido como intermediário pivotal na preparação de 13, tendo-se conduzida a reação de Mannich para a introdução da cadeia lateral alquílica. A rota sintética empregada englobou oito etapas e conduziu a formação de $\mathbf{1 3}$ com rendimento total de $26 \%$. A formação do heterociclo indólico via ciclização redutiva de $o, \beta$-dinitroestireno é também apresentada.
\end{abstract}

The synthesis of 5,6-methylenedioxy-indol-3-yl-methanoic acid $\mathbf{8}$ and 5,6-methylenedioxyindol-3-yl-acetic acid $\mathbf{1 3}$ is described. Piperonal was employed as starting material, and the construction of the heterocyclic ring based on the Hemetsberger reaction of the corresponding $\beta$-azidostyrene was highly regiospecific. Compound $\mathbf{8}$ was obtained as a key intermediate towards $\mathbf{1 3}$, and a Mannich reaction was used to introduce the required alkyl side chain. The route comprised eight steps giving 13 in $26 \%$ overall yield. The formation of the indolic ring via reductive cyclisation of $o, \beta$-dinitrostyrene is also presented.

Keywords: indolecarboxylic acids, nitrene insertion, piperonal, plant growth regulator

\section{Introduction}

Plant growth regulators comprise a large number of structurally diverse compounds capable of regulating many biological processes, including cell division, differentiation and enlargement, chloroplast development and senescence. Their wide use in agriculture and plant biotechnology gives them a relevant role in science and technology. ${ }^{1}$ Distributed in five main classes, the indolic auxines incorporate some of the most important representatives, the endogenous indoleacetic acid-IAA $\mathbf{1}$, 4-chloro-indoleacetic acid-4-CIIAA 2 and indolebutyric acid-IBA 3. ${ }^{2}$

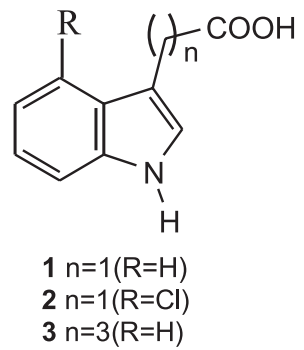

* e-mail: rrcarbon@ furb.br
In order to access compounds with improved properties in comparison to the endogenous auxines and also to establish their structure-activity relationship, several substituted indolecarboxylic acids have been prepared, including a variety of oxygen benzosubstituted indoles. ${ }^{3-6}$ However, the methylenedioxy group frequently found in many secondary metabolities has not received much attention. At this point, it is worth mentioning the work of Barreiro et $a l .{ }^{7}$ which focus on the preparation of indolecarboxylic acid analogue to the anti-inflammatory indomethacin from the methylenedioxyarene safrole.

Therefore, in the search for potential plant growth regulators from abundant natural products and their derivatives, presently is described the synthesis of new methylenedioxyindolecarboxylic acids structurally related to IAA.

\section{Results and Discussion}

For the synthesis of compounds with the general structure 4, Scheme 1, we considered two complementary main disconnections, $D 1$ and $D 2$, where a vinyl azide and $o-\beta$-dinitrostyrene would be the pivotal intermediates in 
the construction of the heterocyclic ring, respectively. Such compounds can be readily accessed by condensation reactions of the appropriate nucleophile and the commercially available piperonal $\mathbf{5}$, a derivative of safrole.

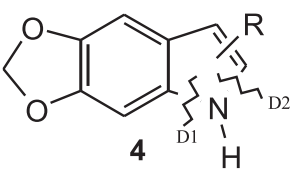<smiles>C=CC=C</smiles><smiles>[R]C=Cc1cc2c(cc1[N+]#N)OCO2</smiles><smiles>C=CCc1ccc2c(c1)OCO2</smiles>

Scheme 1.

For the first synthetic strategy $(D 1)$ the Hemetsberger reaction $^{8}$ was employed (see Scheme 2), and this was initiated with the preparation of the vinyl azide ${ }^{9} \mathbf{6}$ which, upon heating in refluxing xylene, generated the highly electrophilic singlet nitrene species. ${ }^{10}$ Thus, the insertion reaction in a less hindered position proceeded at very high yield, giving the desired indole 7 as a single regioisomer (all coupling constants $<1 \mathrm{~Hz}$ ). ${ }^{11-13}$ Hydrolysis of indol 7 under typical reaction conditions provided the new indole 8, which could be regarded as a potential plant growth regulator since such a property has been associated to some aryl homocyclic carboxylic acids. ${ }^{14}$ For the synthesis of the IAA analogue, the indole unsubstituted heterocyclic ring 9 was required. This was achieved by decarboxylation of indole $\mathbf{8}$ in solid phase at high temperature, in the presence of barium hydroxide, with the product being obtained as an analytically pure compound, since it was separated from the reaction mixture by sublimation.

Before conducting the reactions for the preparation of the acetic acid derivative, it was decided to investigate the disconnection $D 2$ as a means of accessing 9 without employing precursors substituted at the heterocyclic ring. Therefore, the use of the $o, \beta$-dinitrostyrene 11 was examined. ${ }^{15,16}$ This compound can be readily obtained by the condensation reaction of nitromethane and piperonal to give 10, followed by nitration (Scheme 2). Although 9 had already been prepared by Yang and Chen ${ }^{17}$ in very high yield $(94 \%)$, under conditions of catalytic hydrogenation, two other methods were considered. Palladium on carbon with cyclohexene as a source of hydrogen, ${ }^{18}$ a procedure that had not been previously applied to this system, gave the desired compound in a poor $37 \%$ yield. Furthermore, the method has a strong drawback because it requires stoichiometric amount of palladium catalyst. The method of choice, following the literature procedure was the known reductive cyclisation ${ }^{19}$

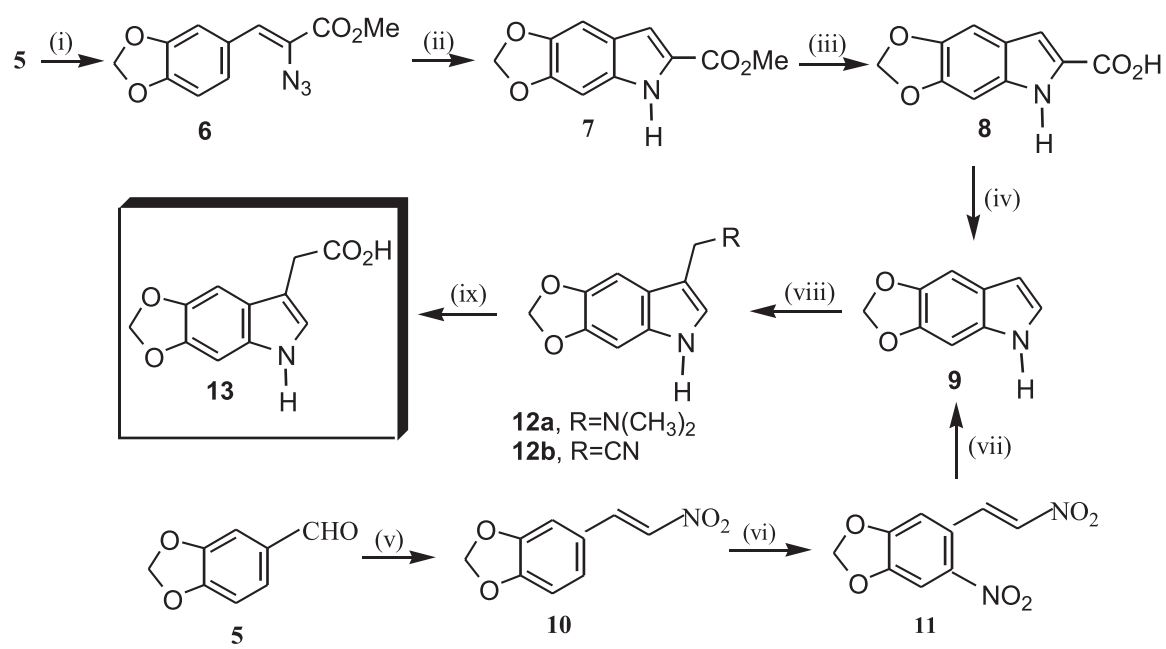

(i) $\mathrm{N}_{3} \mathrm{CH}_{2} \mathrm{COOMe}, \mathrm{MeONa} / \mathrm{MeOH},-10^{\circ} \mathrm{C}, 97 \%$ (ii) Xylene,reflux, $90 \%$ (iii) 1. $\mathrm{NaOH}(\mathrm{aq}$ ); 2. $\mathrm{HCl}(\mathrm{aq}$ ), $92 \%$ (iv) $\mathrm{Ba}(\mathrm{OH})_{2}$, heat, $84 \%$ (v) $\mathrm{CH}_{3} \mathrm{NO}_{2}, \mathrm{AcONH}_{4}, 70 \%$ (vi) $\mathrm{HNO}_{3}, \mathrm{AcOH}, 80 \%$ (vii) $\mathrm{Fe}, \mathrm{AcOH}$, silica gel, benzene-cyclohexane, $72 \%$ (viii) 1. $\mathrm{HN}\left(\mathrm{CH}_{3}\right)_{2}, \mathrm{CH}_{2} \mathrm{O}, \mathrm{AcOH} ; 12 \mathrm{a}, 72 \%$; 2. NaCN, DMF, Mel, $\mathrm{MeOH}$; 12b, 74\% (ix) a. $\mathrm{NaOH}(\mathrm{aq}$ ); b. $\mathrm{HCl}$ (aq), $73 \%$ 
of $\mathbf{1 1}$ assisted by silicagel in a mixture of 1:3 benzene:cyclohexane leading to compound $\mathbf{9}$, as shown in Scheme 2 in $72 \%$ yield (single experiment). The compound prepared in this way showed identical $\left({ }^{1} \mathrm{H}\right.$ and ${ }^{13} \mathrm{C}$ ) NMR spectra as, the compound obtained by decarboxylation of $\mathbf{8}$. Attempts to prepare $\mathbf{9}$ using toluene instead of the hydrocarbon mixture above afforded the desired product in very poor yield, different to that claimed in the literature..$^{20}$

For the introduction of the alkyl side chain, 9 was submitted to a Mannich reaction ${ }^{21}$ to give the expected tertiary amine 12a. In situ quaternization of 12a to provide a better leaving group followed by cyanide nucleophilyc displacement gave $\mathbf{1 2 b}\left(v=2240 \mathrm{~cm}^{-1}\right)$ in very good yield. Finally, basic hydrolysis of $\mathbf{1 2 b}$ and subsequent acidic workup produced the desired indoleacetic acid $13 .{ }^{22,23}$ The total synthesis of the target molecule $\mathbf{1 3}$ was accomplished in eight steps via the vinyl azide $\mathbf{6}$, in a significant overall yield of $26 \%$. On the other hand, the reductive cyclisation of $o, \beta$-dinitrostyrene gave $\mathbf{1 3}$ in six steps, in an overall yield of $16 \%$.

The plant growth regulatory properties of compounds $\mathbf{7 , 8}$ and $\mathbf{1 3}$ are currently under investigation by means of in vitro and in vivo assays. ${ }^{24,25}$

\section{Experimental}

\section{General}

Melting points were determined on Kofler melting point apparatus (Microquímica APF-301) and values were uncorrected. IR spectra were recorded with a Perkin-Elmer 781 Spectrophotometer in $\mathrm{KBr} .{ }^{1} \mathrm{H}$ and ${ }^{13} \mathrm{C}$ NMR spectra were recorded using Brüker Ac 200 and 300 Spectrometers in solvents as indicated with $\mathrm{Me}_{4} \mathrm{Si}$ (TMS) as the internal standard. The mass spectra were obtained on a Shimadzu CGMS-QP-2000-A Spectrometer adapted with an EI source. The elemental analyses were obtained on a Carlo Erba-EA 1110 CHNS-O. Column chromatography was performed using silica gel (70-230 mesh), and the reactions were monitored by TLC (the plates were coated with Merck Kiesegel $60 \mathrm{GF}_{254}$ silica gel). The visualization of the compounds on the chromatograph plates was achieved under ultraviolet light and exposure to iodine vapour.

\section{Methyl azidoacetate}

A mixture of sodium azide ( $26 \mathrm{~g}, 400 \mathrm{mmol})$ in water $(24 \mathrm{~mL})$ was added by stirring to a solution of methyl bromoacetate $(50 \mathrm{~g}, 327 \mathrm{mmol})$ in methanol $(50 \mathrm{~mL})$. The resulting mixture was refluxed for $4 \mathrm{~h}$ after which it was cooled to $25^{\circ} \mathrm{C}$ and the methanol removed under reduced pressure. The crude product was purified under reduced pressure distillation (bp $72-76{ }^{\circ} \mathrm{C}, 30 \mathrm{mmHg}$ ), to provide the methyl azido acetate as a clear liquid $(32.3 \mathrm{~g}, 99 \%$ yield); IR $v_{\text {max }} / \mathrm{cm}^{-1} 2110\left(\mathrm{~N}_{3}\right), 1748(\mathrm{CO})(\mathrm{KBr}) ;{ }^{1} \mathrm{H}$ NMR $\left(300 \mathrm{MHz}, \mathrm{CDCl}_{3}\right) \delta 3.8$ (s, 3H), 3.9 (s, 2H).

Methyl-2-azido(3,4-methylenedioxyphenyl)propenoate (6)

A solution of 3,4-methylenedioxybenzaldehyde (5) $(5.0 \mathrm{~g}, 33 \mathrm{mmol})$ in methanol $(20 \mathrm{~mL})$ and methyl azidoacetate (15.3 g, $133 \mathrm{mmol}$ ) was added dropwise $(1 \mathrm{~h})$ to sodium methoxide solution [prepared from sodium $(3.1 \mathrm{~g}, 135 \mathrm{mmol})$ in methanol $(40 \mathrm{~mL})]$ at $-8{ }^{\circ} \mathrm{C}$. The mixture was then stirred for $2 \mathrm{~h}$, maintaining the temperature below $5{ }^{\circ} \mathrm{C}$. The heterogeneous mixture was poured into ice $(400 \mathrm{~mL})$ and manually stirred. The yellow suspension was filtered, washed with ice water, and dried in a vacuum oven for $12 \mathrm{~h}$ at $70{ }^{\circ} \mathrm{C}$. The yellow solid $(7.98 \mathrm{~g}$, $97 \%$ yield) was used without further purification in the next step. IR $v_{\max } / \mathrm{cm}^{-1} 2124\left(\mathrm{~N}_{3}\right), 1710(\mathrm{CO}), 1256$ (COC) $(\mathrm{KBr}) ;{ }^{1} \mathrm{H} \mathrm{NMR}\left(300 \mathrm{MHz}, \mathrm{CDCl}_{3}\right) \delta 3.9$ (s, 3H), 6.01 (s, $2 \mathrm{H}), 6.8(\mathrm{~d}, 1 \mathrm{H}, J 8.38 \mathrm{~Hz}), 6.84(\mathrm{~s}, 1 \mathrm{H}), 7.16(\mathrm{~d}, 1 \mathrm{H}, J 8.02$ $\mathrm{Hz}), 7.58(\mathrm{~s}, 1 \mathrm{H})$.

Methyl-5,6-methylenedioxyindol-2-yl-carboxylate (7)

A mixture of methyl-2-azido-(3,4-methylenedioxyphenyl)propenoate (6) $(2.0 \mathrm{~g}, 8.1 \mathrm{mmol})$ and xylene $(75 \mathrm{~mL})$ was refluxed for $3 \mathrm{~h}$, when the evolution of $\mathrm{N}_{2}$ had ceased. The xylene was removed under reduced pressure distillation, and the resulting solid was purified by column chromatography, using a mixture of dichloromethane and ethyl acetate (20:5) for elution and providing the pure product (1.6g, 90\%); $\mathrm{mp} 173.2-174.6^{\circ} \mathrm{C}$; IR $v_{\max } / \mathrm{cm}^{-1} 3324$ (NH), $3072(\mathrm{CH}), 1696(\mathrm{CO}), 1248(\mathrm{COC})(\mathrm{KBr})$; Elemental analysis: Found: C, 59.98; H, 4.28; N, 6.26. Calc. for $\mathrm{C}_{11} \mathrm{H}_{9} \mathrm{NO}_{4}: \mathrm{C}, 60.27 ; \mathrm{H}, 4.13 ; \mathrm{N}, 6.39 \%$; ${ }^{1} \mathrm{H} \mathrm{NMR}(300 \mathrm{MHz}$, $\left.\mathrm{CDCl}_{3}\right) \delta 3.88(\mathrm{~s}, 3 \mathrm{H}), 5.93(\mathrm{~s}, 2 \mathrm{H}), 6.91(\mathrm{~d}, 1 \mathrm{H}, J 0.36 \mathrm{~Hz})$, $6.94(\mathrm{~d}, 1 \mathrm{H}, J 0.36 \mathrm{~Hz}), 7.02(\mathrm{dd}, 1 \mathrm{H}, J 0.9$ and $0.84 \mathrm{~Hz})$ 11.03 (s, $1 \mathrm{H}, \mathrm{NH}) ;{ }^{13} \mathrm{C} \mathrm{NMR}\left(50 \mathrm{MHz}, \mathrm{CDCl}_{3}\right) \delta 51.4,92.4$, 99.2, 100.7, 108.5, 121.2, 125.1, 133.5, 143.8, 147.4, 162.1; MS: $m / z 219\left(\mathbf{M}^{+}, 76 \%\right), 187$ (100), 159 (67), 133 (25), 101 (34), 93 (22), 75 (25), 50 (27).

\section{5,6-Methylenedioxyindol-2-yl-methanoic acid (8)}

A mixture of methyl-5,6-methylenedioxyindol-2-ylcarboxylate (7) $(2.3 \mathrm{~g}, 10 \mathrm{mmol})$ and sodium hydroxide $\left(2 \mathrm{~N}, 50 \mathrm{~mL}\right.$ ) was refluxed for $1 \mathrm{~h}$, cooled to $25^{\circ} \mathrm{C}$, and acidified with a solution of $\mathrm{HCl}(6 \mathrm{~N}, 60 \mathrm{~mL})$. The resulting 
precipitate was filtered, washed with ice water, and dried in the vacuum oven. The solid was crystallized from methanol giving the pure acid (1.99 $\mathrm{g}, 92 \%)$; mp $250.9{ }^{\circ} \mathrm{C}$ with decomposition; IR $v_{\text {max }} / \mathrm{cm}^{-1} 3344(\mathrm{NH}), 2914(\mathrm{OH}), 1706$ (CO), 1288 (COC) (KBr); elemental analysis: Found: C, 58.53; H, 3.42; N, 6.83. Calc. for $\mathrm{C}_{10} \mathrm{H}_{7} \mathrm{NO}_{4}: \mathrm{C}, 58.54 ; \mathrm{H}$, $3.44 ; \mathrm{N}, 6.83 \%$; ${ }^{\mathrm{H}} \mathrm{NMR}\left(300 \mathrm{MHz}, \mathrm{DMSO}-\mathrm{d}_{6}\right) \delta 5.93$ (s, $2 \mathrm{H}), 6.91(\mathrm{~s}, 1 \mathrm{H}), 6.94(\mathrm{~s}, 1 \mathrm{H}), 7.02(\mathrm{dd}, 1 \mathrm{H}, J 0.81$ and 0.48 $\mathrm{Hz}), 11,6$ (s, 1H, indole); ${ }^{13} \mathrm{C}$ NMR $(50 \mathrm{MHz}$, DMSO-d 6$)$ 92.4, 98.2, 100.8, 108.3, 121.2, 125.0, 133.2, 143.6, 147.2, 163.2; MS: m/z $205\left(\mathrm{M}^{+}, 80 \%\right), 187$ (100), 159 (90), 129 (20), 101 (50), 93 (27), 75 (33), 50 (45).

\section{5,6-Methylenedioxyindole (9)}

A mixture of 5,6-methylenedioxyindol-2-yl-methanoic acid (8) (0.72 g, $3.5 \mathrm{mmol})$ and barium hydroxide $(0.17 \mathrm{~g}$, $0.55 \mathrm{mmol})$ was finely ground and heated in "cold trap" using a Bunsen flame under vacuum $(20-30 \mathrm{mmHg})$. The solid was sublimed to provide the pure indole $(0.47 \mathrm{~g}$, 84\%); mp 109.4-110 ${ }^{\circ} \mathrm{C}$ (Lit. ${ }^{16} 108-110{ }^{\circ} \mathrm{C}$ ); IR $v_{\max } / \mathrm{cm}^{-1}$ $3410(\mathrm{NH}), 1206$ (COC) (KBr); ${ }^{1} \mathrm{H} \mathrm{NMR}\left(200 \mathrm{MHz}, \mathrm{CDCl}_{3}\right)$ $\delta 5.92(\mathrm{~s}, 2 \mathrm{H}), 6.42(\mathrm{~s}, 1 \mathrm{H}), 6.84(\mathrm{~s}, 1 \mathrm{H}), 7.00(\mathrm{~s}, 1 \mathrm{H}), 7.06$ $(\mathrm{s}, 1 \mathrm{H}), 8.02$ (s, $1 \mathrm{H}$, indole); ${ }^{13} \mathrm{C}\left(50 \mathrm{MHz} \mathrm{CDCl}_{3}\right) \delta 91.8$, 99.1, 100.5, 102.8, 121.6, 122.7, 130.6, 143, 144.9; MS: m/z $161\left(\mathrm{M}^{+}, 100 \%\right), 103$ (38), 76 (33), 50 (23).

\section{5,6-Methylenedioxyindol-3-yl-acetonitrile (12b)}

To a mixture of dimethylamine $(0.87 \mathrm{~g}, 19 \mathrm{mmol}, 35 \%)$ and glacial acetic acid $(1.7 \mathrm{~g}, 28 \mathrm{mmol})$ at $5{ }^{\circ} \mathrm{C}$, formaldehyde $(0.64 \mathrm{~g}, 21 \mathrm{mmol}, 37 \%)$ was added. The mixture was stirred and poured into a flask containing 5,6methylenedioxyindole (9) (1.0 g, $6.2 \mathrm{mmol})$, allowed to stand for $5 \mathrm{~h}$ and was then added slowly to a solution of sodium hydroxide ( $\left.9 \mathrm{~mL}, 3.4 \mathrm{~mol} \mathrm{~L}^{-1}\right)$. The suspension was filtered, washed with ice water, dried in the vacuum oven, provinding the crude 5,6-methylenedioxy-3(dimethylaminomethyl)-indole (12a).

To a suspension of the crude 12a (0.93 g, $4.3 \mathrm{mmol})$ and sodium cyanide $(0.9 \mathrm{~g}, 18.4 \mathrm{mmol})$ in methanol (13 $\mathrm{mL})$ was added dropwise and under stirring dimethylformamide $(0.6 \mathrm{~mL})$, water $(0.6 \mathrm{~mL})$ and methyl iodide (1.4 $\mathrm{mL}, 22 \mathrm{mmol})$. The suspension was continuously stirred for an additional $2 \mathrm{~h}$, after which it was poured into cold water. The precipitate was filtered, washed with ice water and dried in the vacuum oven $\left(70{ }^{\circ} \mathrm{C}\right)$. The product $\mathbf{1 2 b}$ was purified by column chromatography using ethyl acetate and dichloromethane (4:1) as eluent (0.63 g, 74\%); mp 145.4-146.3 ${ }^{\circ} \mathrm{C}$; IR $v_{\max } / \mathrm{cm}^{-1} 3416(\mathrm{NH}), 2240(\mathrm{CN})$ (KBr); elemental analysis: Found: C, 65.50; H, 4.11; N, 13.65. Calc for $\mathrm{C}_{11} \mathrm{H}_{8} \mathrm{~N}_{2} \mathrm{O}_{2}$ : C, 65.99; $\mathrm{H}, 4.02 ; \mathrm{N}, 13.99 \%$; ${ }^{1} \mathrm{H} \mathrm{NMR}\left(200 \mathrm{MHz}, \mathrm{CDCl}_{3}\right) \delta 3.76(\mathrm{~s}, 2 \mathrm{H}), 5.96(\mathrm{~s}, 2 \mathrm{H})$, $6.84(\mathrm{~s}, 1 \mathrm{H}), 6.94(\mathrm{~s}, 1 \mathrm{H}), 7.10(\mathrm{~s}, 1 \mathrm{H}), \sim 8.02(\mathrm{~s}, 1 \mathrm{H}$, indole); ${ }^{13} \mathrm{C} \mathrm{NMR}\left(50 \mathrm{MHz}, \mathrm{CDCl}_{3}\right) \delta 14.5,93.5,97.8,101.8,106,0$ 119.8, 121.4, 123.2, 123.3, 144.2, 146.3; MS: $m / z 200$ $\left(\mathrm{M}^{+} 100 \%\right), 174$ (25).

\section{5,6-Methylenedioxyindol-3-yl-acetic acid (13)}

5,6-Methylenedioxyindol-3-yl-acetonitrile (12b) (0.97 $\mathrm{g}, 4.8 \mathrm{mmol})$ was added to an aqueous solution of potassium hydroxide $(10 \mathrm{~mL}, 20 \%)$. The mixture was heated under reflux for $5 \mathrm{~h}$, cooled to room temperature and acidified with aqueous hydrochloric acid $\left(2 \mathrm{~mol} \mathrm{~L}^{-1}\right)$. The precipitate formed was filtered, washed with ice water and dried in the vacuum oven to $70{ }^{\circ} \mathrm{C}$. The solid was crystallized from water providing the pure acid $(0,77 \mathrm{~g}$, $73 \%$ ); mp 176-176.6 ${ }^{\circ} \mathrm{C}$; IR $v_{\max } / \mathrm{cm}^{-1} 3400(\mathrm{NH}), 2908$ (OH), 1698 (CO) (KBr); Found: C, 60.58; H, 4.67; N, 6.36. Calc. for $\mathrm{C}_{11} \mathrm{H}_{9} \mathrm{NO}_{4}$ : C, 60.27; H, 4.13; N, 6.39\%; ${ }^{1} \mathrm{H}$ NMR $\left(200 \mathrm{MHz}\right.$, acetone $\left.d_{6}\right) \delta 3.66(\mathrm{~s}, 2 \mathrm{H}), 5.89(\mathrm{~s}, 2 \mathrm{H}), 6.86(\mathrm{~s}$, 1H), $7.01(\mathrm{~s}, 1 \mathrm{H}), 7.12(\mathrm{~s}, 1 \mathrm{H}), 9.92\left(\mathrm{~s}, 1 \mathrm{H}\right.$, indole); ${ }^{13} \mathrm{C}$ NMR $\left(50 \mathrm{MHz}\right.$, Acetone- $\left.d_{6}\right) \delta$ 92.8, 98.2, 101.1, 109.2, 122.4, 123, 123.2, 132.3, 143.4, 145.5, 173.3; MS: $m / z$ $219\left(\mathrm{M}^{+}, 60 \%\right), 174(100)$.

\section{Conclusions}

The synthesis of 2 new indolecarboxylic acids incorporating the methylenedioxy subunit has been successfully achieved from the commercially available piperonal, an important derivative of the natural product safrole. Both nitrene insertion reaction from vinylazide and reductive cyclization from $o-\beta$-dinitrostyrene were efficient in the construction of the indole heterocyclic ring. The regulatory properties of compounds $\mathbf{7 , 8}$ and $\mathbf{1 3}$ are currently under investigation to establish their potential as plant growth regulators.

\section{Acknowledgements}

The authors are grateful for financial support from CAPES. The facilities provided by UFSC and FURB are also acknowledged. Thanks are also due to Prof. Franco Delle Monache, Universita Cattolica Del Sacro Cuore, Roma, for the $300 \mathrm{MHz}$ spectra. 


\section{References}

1. Davies, J. P.; Plant Hormones: Physiology, Biochemistry and Molecular Biology, $2^{\text {nd }}$ ed.; Kluwer Academic Publishers: Netherlands, 1995.

2. Kende, H.; Zeevaart, J. A. D.; Plant Cell. 1997, 9, 1197.

3. MacMillan, J.; Encyclopedia of Plant Physiology, SpringVerlag: Berlin, 1980, 9, 681.

4. Roberts, J. A.; Hooley, R.; Plant Growth Regul. Blackie: Glasgow, 1988, 190.

5. Shingo, M.; Masato, K.; Japanese Patent Office JP62077366A, 1987.

6. Shingo, M.; Masato, K.; Japanese Patent Office JP01228962A, 1989.

7. Barreiro, E. J; Costa, P. R. R.; Barros, P. R. V. R.; Queiroz, W. M.; J. Chem. Res. (S). 1982, 102.

8. Gilchrist, T. L.; Aldrichimica Acta 2001, 34, 51.

9. Gribble, G. W.; J. Chem. Soc., Perkin Trans. I 2000, 1045.

10. Lindley, J. M.; McRobbie, I. M.; Meth-Cohn, O.; Suschitzky, H.; Tetrahedron Lett. 1976, 4513.

11. Labarca, C.V.; Mackenzie, A.R.; Moody, C. J.; Rees C. W.; Vaquero, J.; J. Chem. Soc., Perkin Trans. I 1987, 927.

12. Allen, M. S.; Hamaker, L. K.; Loggia, A. J. L.; Cook, J. M.; Synth. Commun. 1992, 22, 2077.

13. Sadanandan, E. V.; Pillai, S. K.; Lakshmikantham, M. V.; Billimoria, A. D.; Culpepper, J. S.; Cava, M. P.; J. Org. Chem. 1995, 60, 1800 .
14. Katekar, G. F.; Phytochemistry 1979, 18, 223.

15. Chen, C.-M.; Fu, Y.-F.; Yang, T.-H.; J. Nat. Prod. 1995, 58, 1767.

16. Dallacker, F.; Bernabei, D.; Monatsh. Chem. 1967, 98, 785.

17. Yang, L.-M.; Chen, C.-F.; Lee, K.-H.; Bioorg. Med. Chem. Lett. 1995, 5, 465.

18. Bontemps, N.; Delfourne, E.; Bastide, J.; Francisco, C.; Bracher, F.; Tetrahedron 1997, 53, 1743.

19. Fukuyama, Y.; Iwatsuki, C.; Kodama, M.; Tetrahedron 1998, 54, 10007.

20. Sinhababu, A. K.; Borchardt, R. T.; J. Org. Chem. 1983, 48, 3347.

21. Flaugh, E. M.; Crowell, A. T.; Clemens, A. J.; Sawyer, D. B.; J. Med. Chem. 1979, 22, 63.

22. Snyder, H. R.; Smith, W. C.; Stewart, M. J.; J. Am. Chem. Soc. 1944, 66, 200.

23. Snyder, H. R.; Pilgrim, F. J.; J. Am. Chem. Soc. 1948, 70, 3770 .

24. Einhellig, F. A.; Schan, M. K.; Rasmunsen, J. A.; Plant Growth Regul. 1983, 1, 251.

25. Rosa, F. A. F., Nascimento, M. G., Rebelo, R. A., Pescador, R.; Abstracts of the 23a Reunião Anual da Sociedade Brasileira de Química, Poços de Caldas, Brazil, 2000; Rosa, F. A. F.; Nascimento, M. G.; Rebelo, R. A.; Pescador, R.; Abstracts of the 51ํㅡㄹ Congresso Nacional de Botânica, Brasília, Brazil, 2000.

Received: January 9, 2002 Published on the web: October 18, 2002 